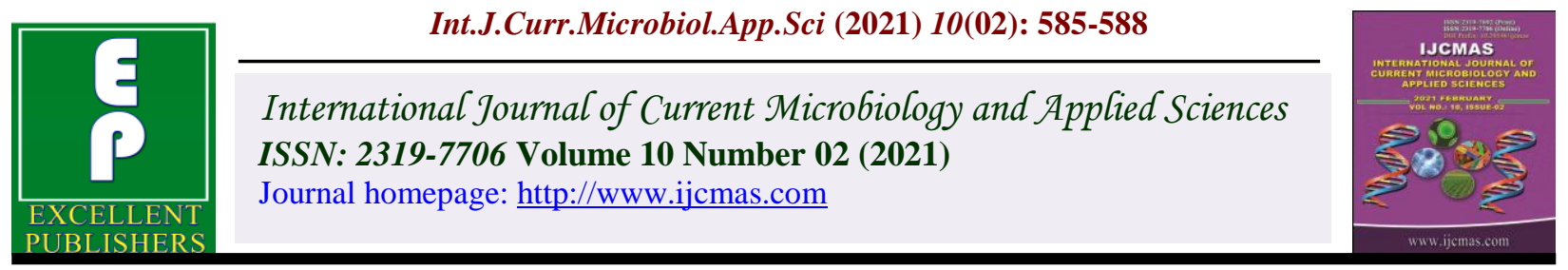

Original Research Article

https://doi.org/10.20546/ijcmas.2021.1002.069

\title{
Existing Technology of Wheat Growers in Begumganj Tehsil of Raisen District of Madhya Pradesh
}

\author{
S. K. Sharma*, P. K. Mishra, R. F. Ahirwar and O. P. Dhurve \\ JNKVV, College of Agriculture, Ganj basoda, India \\ *Corresponding author
}

\section{A B S T R A C T}

\section{Keywords}

Improved package of practice, Training wheat, Energy consumption

\section{Article Info}

Accepted:

07 January 2021

Available Online:

10 February 2021
The present study was conducted during 2015 under Krishi Mahotsav programme organized by Department of Farmer Welfare and Agriculture Development, Govt. of Madhya Pradesh. 375 farmers were selected from 15 villages of Begumganj tehsil of Raisen district. The present study was carried with the objectives to training needs of wheat growers towards recommended production technologies with optimize the energy consumption to enhance the wheat production. Farmers have been growing wheat during rabi season long time but the production is very low. Therefore farmers need to be trained about improved package and practice of wheat.

\section{Introduction}

Indian agriculture continues to face internal \& external challenges. While monsoon dependence, fragmented land holding, low level of input usages, antiquated agronomic practice, lack of technology application and poor rural infrastructure, top surface soil degradation hazards due to uncontrolled surface runoff, lack of low cost technology of gulley, nala treatments for rain water harvesting and also to check erosive velocity of water in perennial streams of watershed area in order to safeguard against erosion hazards are some of the key internal constraints to this area for wheat production.
However to enhance the productivity of wheat the replacement of human labour, synthetic fertilizer and pesticides, selective breeding and mechanization have been undertaken. Wheat has pivotal role in ensuring food security of the country. Wheat is the world's most widely cultivated cereal crop and in India, it is the second most important staple cereal food after rice. It is not only the staple food for wheat consuming population of India but also major source of the dietary energy. Worldwide wheat provides nearly $55 \%$ of the carbohydrate and $20 \%$ of the food calories consumed globally (Breiman and Graur, 1995). Wheat is used by human being in form of flour for making chapaties, semolina and 
pasta products. It is also used for preparation of bread, biscuits, cookies, cracks, noodles, dalia, maida, vermicelli etc. Wheat straw is also used for the animal feed as fodder and for the packaging materials. The wheat contains nearly carbohydrates $70 \%$, protein $12 \%$, fat $1.7 \%$, minerals $2.7 \%$, fibre $2 \%$, and moisture $12 \%$.

Wheat is world's leading cereal crop, cultivated near about $216.6 \mathrm{~m}$ ha with a production of $674.88 \mathrm{~m}$ t of grain with 3150 $\mathrm{kg} /$ ha productivity (2012-13). In India, wheat was cultivated in about $29.1 \mathrm{~m}$ ha of the total cultivated area with an annual production of $84.27 \mathrm{~m} \mathrm{t}$ (Ministry of Agriculture, GOI 2011). The average productivity of wheat in India is $29.0 \mathrm{q} /$ ha whereas $47 \mathrm{q} / \mathrm{ha}$ in China and $31 \mathrm{q} / \mathrm{ha}$ in USA (Chakravarty,2011). In Madhya Pradesh, it is cultivated in 5.29 M ha of land with an annual production of $9.00 \mathrm{~m} \mathrm{t}$ and productivity of $1700 \mathrm{~kg} / \mathrm{ha}$ (CLRS, 2008). As per an estimate about $130 \mathrm{~m} \mathrm{t}$ of wheat is required by 2030 for feeding and growing Indian population. There is no scope for area expansion, additional production has to achieve by increasing per hectare productivity (Nagarajan, 1997). Development of new high yielding varieties, production technologies and dissemination of improved wheat production technologies among farming communities are the few options available to increase the wheat productivity of the country. Looking to these facts, the present study was carried out with the objectives to ascertain the growers training needs of wheat production technologies. Training and demonstration are the critical inputs for quick transfer of the technologies. Thus the importance of the training is an indispensable instrument for human resource development at any level cannot be ignored. In order to make any training meaningful and effective the training needs of the farmers. So that the specific subject matter of the training could be determined on the basis of the assessment of need (Singh et al., 2002 and Gupta et al., 2008).

\section{Materials and Methods}

The present study was conducted during 2015 under Krishi Rath / Krishi Mahotsav programme organized by Departmnet of Farmers Welfare and Agriculture Development, Govt. Of Madhya Pradesh. 375 farmers were selected from fifteen villages viz. Khamaria, Tekapar, Pandajhir, Bahmori, Kokalpur, Sumer, Kalyanpur, Chandoriya, Sultanganj, Padariya Rajadhar, Markheda Gulab, MarkhedaTappa, Paloh, Kiratpur, Lakhanpur of Begumganj tehsil Raisen district of Madhya Pradesh, India. Out of these 375 farmers 25 farmers were selected purposively from each village. An interview schedule was prepared in view of the objectives of the study and data were collected by personal interview from the wheat growers. The practice wise training needs of the wheat production technology was assessed using a three point scale such as high needed, medium needed, and low needed was 3,2 and 1 respectively.

\section{Results and Discussion}

Data regarding distribution of respondents according to their training needs were collected and classified in three categories. The data of Table 1 showed that 76.00 per cent respondents were under high training needs whereas 14.13 per cent respondents have medium training need and remaining 9.87 per cent have low training need. It can be concluded that majority of the wheat growers have high training needs. The data of Table 2 showed that among all the agricultural practices of wheat production technology, high yielding varieties was ranked I ${ }^{\text {st }}(2.85)$ as far as training needs of respondents concerned. 
Table.1 Distribution of wheat growers according to their training needs $(\mathrm{N}=375)$

\begin{tabular}{|l|l|c|c|}
\hline S.No. & Knowledge level & Frequency & Per cent \\
\hline 1. & Low & 37 & 9.87 \\
\hline 2. & Medium & 53 & 14.13 \\
\hline 3. & High & 285 & 76.00 \\
\hline
\end{tabular}

Table.2 Details of training needs for production technology by wheat growers $(\mathrm{N}=375)$

\begin{tabular}{|c|c|c|c|c|c|c|c|c|}
\hline \multirow[t]{2}{*}{ S.No. } & \multirow{2}{*}{$\begin{array}{l}\text { Package } \\
\text { practices }\end{array}$} & \multicolumn{3}{|c|}{ Score values } & \multirow{2}{*}{$\begin{array}{l}\text { Total } \\
\text { score }\end{array}$} & \multirow{2}{*}{$\begin{array}{l}\text { Mean } \\
\text { score } \\
\text { value }\end{array}$} & \multirow[t]{2}{*}{ Ranking } & \multirow{2}{*}{$\begin{array}{l}\text { Extent } \\
\text { Training } \\
\text { need }\end{array}$} \\
\hline & & (3) & (2) & (1) & & & & \\
\hline 1. & Land preparation & $\begin{array}{l}102 \\
(34)\end{array}$ & $\begin{array}{l}96 \\
(48)\end{array}$ & $\begin{array}{l}293 \\
(293)\end{array}$ & 491 & 1.30 & XI & Low \\
\hline 2. & Seed rate & $\begin{array}{l}906 \\
(302)\end{array}$ & $\begin{array}{l}118 \\
(59)\end{array}$ & $\begin{array}{l}14 \\
(14)\end{array}$ & 1038 & 2.77 & III & High \\
\hline 3. & Seed treatment & $\begin{array}{l}792 \\
(294)\end{array}$ & $\begin{array}{l}108 \\
(54)\end{array}$ & $\begin{array}{l}27 \\
(27)\end{array}$ & 927 & 2.47 & IX & High \\
\hline 4. & Sowing time & $\begin{array}{l}78 \\
(26)\end{array}$ & $\begin{array}{l}68 \\
(39)\end{array}$ & $\begin{array}{l}310 \\
(310)\end{array}$ & 456 & 1.21 & XII & Low \\
\hline 5. & Spacing & $\begin{array}{l}834 \\
(278)\end{array}$ & $\begin{array}{l}164 \\
(82)\end{array}$ & $\begin{array}{l}15 \\
(15)\end{array}$ & 1013 & 2.70 & VII & High \\
\hline 6. & $\begin{array}{l}\text { High yielding } \\
\text { varieties }\end{array}$ & $\begin{array}{l}987 \\
(329)\end{array}$ & $\begin{array}{l}72 \\
(36)\end{array}$ & $\begin{array}{l}10 \\
(10)\end{array}$ & 1069 & 2.85 & I & High \\
\hline 7. & $\begin{array}{l}\text { Manures and } \\
\text { fertilizers application }\end{array}$ & $\begin{array}{l}888 \\
(296)\end{array}$ & $\begin{array}{l}94 \\
(47)\end{array}$ & $\begin{array}{l}36 \\
(36)\end{array}$ & 1018 & 2.71 & VI & High \\
\hline 8. & Irrigation & $\begin{array}{l}903 \\
(301)\end{array}$ & $\begin{array}{l}116 \\
(58)\end{array}$ & $\begin{array}{l}16 \\
(16)\end{array}$ & 1035 & 2.76 & IV & High \\
\hline 9. & Weed management & $\begin{array}{l}969 \\
(323)\end{array}$ & $\begin{array}{l}82 \\
(41)\end{array}$ & $\begin{array}{l}11 \\
(11)\end{array}$ & 1062 & 2.83 & II & High \\
\hline 10. & Insect control & $\begin{array}{l}891 \\
(297)\end{array}$ & $\begin{array}{l}114 \\
(57)\end{array}$ & $\begin{array}{l}21 \\
(21)\end{array}$ & 1026 & 2.73 & V & High \\
\hline 11. & Disease control & $\begin{array}{l}903 \\
(301)\end{array}$ & $\begin{array}{l}70 \\
(35)\end{array}$ & $\begin{array}{l}39 \\
(39)\end{array}$ & 1012 & 2.69 & VIII & High \\
\hline 12. & $\begin{array}{l}\text { Harvest and post } \\
\text { harvest }\end{array}$ & $\begin{array}{l}321 \\
(107)\end{array}$ & $\begin{array}{l}434 \\
(217)\end{array}$ & $\begin{array}{l}51 \\
(51)\end{array}$ & 806 & 2.15 & X & Low \\
\hline \multicolumn{6}{|c|}{ Overall mean score } & \multicolumn{3}{|l|}{2.28} \\
\hline
\end{tabular}

3- high needed, 2- medium needed, 1- low needed

The practices like weed management was put at rank $\mathrm{II}^{\text {nd }}(2.83)$, seed rate at $\mathrm{III}^{\text {rd }}(2.77)$, irrigation at $\mathrm{IV}^{\text {th }}(2.76)$, insect control at $\mathrm{V}^{\text {th }}$ (2.73), manure and fertilizer application at $\mathrm{VI}^{\text {th }}$ (2.71), spacing at $\mathrm{VII}^{\text {th }}(2.70)$, disease control at VIII ${ }^{\text {th }}(2.69)$ and seed treatment at
$\mathrm{IX}^{\text {th }}$ (2.47) respectively. This means that the wheat growers gave highest emphasis on high yielding varieties, as this information can help them to great extent while adopting in their fields. The other practices viz., harvest and post harvest, land preparation and sowing 
time were ranked at $\mathrm{X}^{\text {th }}(2.15), \mathrm{XI}^{\text {th }}(1.30)$ and $\mathrm{XII}^{\text {th }}(1.21)$ respectively. The overall mean score was found to be 2.28 means there by that the farmers expressed their desires high need of training in all the selected areas.

\section{References}

Breiman, A. and Graur, D. 1995. Wheat evolution. Israel Journal of Plant Sciences. 43: pp 85-89. http://www.faostat3. fao.org

C.L.R.S. 2008. Published by Commissioner Land Records and Settlements, Gwalior, Madhya Pradesh.

Chakravarty, K.C. 2011. The National Seminar on Productivity in Indian Agriculture at CAB, Pune on Sept. 2, 2011.

Gupta, A.K., Singh, Y.K. and Verma, S.
2008. Training needs as perceived by tribal farmers with respect to soybean cultivation. New Agriculturist. 19 (1\&2): p. 25-27

Ministry of Agriculture, GOI 2011. Third advance estimate of Agriculture Ministry, Govt. of India , New Delhi.

Nagarajan, S. 1997. Perspectives on wheat demand and research needs. Wheat research needs beyond 2000 AD. Proc. Int. Group meeting held at DWR, Karnal India. 12-14. Aug. 1997, p. 1415

Singh, R.K., Rai A.K. and Payasi, V.K. 2002. Adoption and training needs of potato production technology among small farmers. J.N.K.V.V. Res. J. 36 (1\&2): 66-68.

\section{How to cite this article:}

Sharma, S. K., P. K. Mishra, R. F. Ahirwar and Dhurve, O. P. 2021. Existing Technology of Wheat Growers in Begumganj Tehsil of Raisen District of Madhya Pradesh. Int.J.Curr.Microbiol.App.Sci. 10(02): 585-588. doi: https://doi.org/10.20546/ijcmas.2021.1002.069 